\title{
THE CONCEPT OF AN ARMY AS A PSYCHIATRIC CASUALTY
}

\author{
LT COL WILLIAM R CLINE, MC*
}

Neuropsychiatric Consultant, 7th Medical Command, US Army in Europe

\author{
LT COL FRANK H RATH, MSC* \\ US Army MEDDAC, Fort Gordon
}

SUMMARY: The psychiatric battle casualty, an individual soldier who becomes ineffective in battle for emotional reasons, has been extensively described and is common in modern war. This type of battle casualty collectively leads to a major loss of soldiers in combat. Less often considered are groups in combat, groups as large as entire armies, which also may in effect become psychiatric casualties. History gives many examples of major military defeats caused as much by psychological as by strategic or material factors. The French army in WW II is considered as an example of an army which may be viewed as a psychiatric casualty, and it is used to emphasize the importance of a study of factors which put armies at risk of psychological collapse in battle.

\section{Introduction}

Over the centuries great attention has been paid to the reasons why armies win and lose wars. Easily identified tangible factors affecting performance of an army are resources, size, wealth and technology of a nation and its armed forces. Another important factor is the level of training of soldiers and units within the army. A further factor of great importance, less easily quantified, is that of the morale or fighting spirit of an army. This last factor is seen as most important by many military writers. Every military historian can identify examples of victorious armies which were inferior materially, but which won through to superior morale and fighting spirit.

In a broad sense, the terms morale and fighting spirit are psychological concepts. They are, however, subject to varying definition and are not automatically related to psychiatric principles which have evolved in the 20th century. These terms are easily seen as inherent to good small group cohesiveness and effective leadership of larger groups, but are less easily seen as inherent to the collective psychology of all members of large groups ${ }_{1}$.

What is usefully studied, regarding the psychology of armies? In particular, what can be learned from a study of the psychology of defeated armies? Should that psychology be studied as carefully as the psychology of victorious armies? If it is studied, what points of view will yield the most knowledge? In the study

${ }^{*}$ The views expressed in this article are those of the authors and do not purport to reflect the position of the United States Department of the Army, the Department of Defence or any other government agency. 
of entire armies, should the psychology of the individual soldier be most closely studied, or might it be even more useful to study the psychology of the large group? The thesis of this paper is that armies may usefully be viewed as single psychological entities subject to pressures similar to those on individual soldiers, and armies like individual soldiers are at risk of becoming "psychiatric casualties." The theoretical underpinnings for the leap from the psychology of individual soldiers to the psychology of an army as a large group are the works of Freud on groups ${ }^{2,}$, , greatly developed and expanded by writers who are often referred to as the Tavistock school of group process ${ }^{4-7}$. The approach of studying specific group processes in armies derived its impetus in turn from the experience of the British army in WWII ${ }^{8}$.

\section{The Individual Psychiatric Casualty}

The individual as a psychiatric casualty in combat has been thoroughly noted and described in this century ${ }^{9-11}$. Since WW I it has been known that, due to the extreme pressures of battle, some soldiers who otherwise show no signs of mental illness develop severe psychological symptoms which render them ineffective in combat. Largely depending on the treatment they receive the ineffectiveness may be temporary or permanent. The traditional principles of "immediacy, proximity, expectancy," when correctly applied, lead to a return to duty of the majority of individual psychiatric casualties. In soldiers who do not have clear pre-existing mental illness it has been found difficult to predict in advance who is most at risk of becoming a psychiatric casualty, but it has been noted that the intensive training and extremely strong group cohesiveness that are characteristic of "crack" units seem to give individual soldiers a resistance against becoming psychiatric casualties, whereas poorly trained troops newly placed in fighting units seem to be at greatest risk of becoming casualties.

\section{The Group Psychiatric Casualty}

The thesis that groups may also become psychiatric casualties presumes that, as with individuals, groups composed of competent members and adequate equipment may, from psychological causes, become ineffective in the accomplishment of their battle tasks. It is beyond the scope of this paper extensively to discuss groups in general, but for the purposes of discussion a group will be defined as a collection of individuals who share a common boundary (physical or psychological) and task (concrete or symbolic) and are interrelated by the authority relationships inherent in their roles in the group.

The most basic group is, of course, the family. Family therapists treat families which become ineffective in providing for their basic needs of security and development, and the phenomenon of an entire family appearing to collapse under stress is not rare. Psychiatrists have less experience thinking of larger groups in terms of the concept of a psychiatric casualty. At the other extreme from the family, the largest conceivable group in which we interact is the population of the earth. Subgroups, first of nations, races, etc., may be conceptualized in decreasing size, all the way back down to the family. When large 
groups become ineffective in their tasks, reviewing the failures from a psychological group process point of view may lead to insights not otherwise available when the more usual points of view such as historical, sociological or economic are used.

A nation's army is a very large, well defined group which, in a group process sense, may be seen as having a primary task of maintaining and sometimes expanding a nation's boundaries. An army fails in its task when the nation is defeated in war. Defeats certainly may follow deficiencies of resources, but just as the performance of individual soldiers in combat is influenced by their psychology, the success or failure of an army is subject to psychological influences. Abrupt, utter failure by an apparently strong army to accomplish its task suggests that the psychological factors may be of paramount importance, or that in other words, the army has become a psychiatric casualty. To exemplify the concept of an army as a group psychiatric casualty a case study has been chosen, with a review of its prodrome and ultimate collapse. Then a modern army with different but important psychological risk factors will be reviewed.

\section{The French Army in WW II}

The French Army in WW II may be seen as an example of an army which became a psychiatric casualty. In May-June 1940 the French army collapsed before the onslaught of the German Blitzkrieg ${ }^{12-18}$. This event shocked the world, particularly since by all reasonable standards of war the French army should have been a formidable opponent to the Germany army. A fact commonly forgotten today is that in the material sense the French army (in particular with its British allies, and with the Belgians and Dutch who became allies after Germany violated their neutrality) was as strong as the German army. France had as many troops and tanks as the German army. It was inferior only in planes, and those which existed were not effectively used. The French tanks have been considered by some historians to be of at least equal quality to those of the Germans. France was fighting a defensive battle on her own territory, usually an advantage. There is no doubt that Germany was superior both strategically and tactically, but the tactics used by Germany with her panzer units were tactics first described by the British and French. Unlike in WW I when France had the resilience to recover from initial setbacks, in WW II defeat advanced at an accelerating pace. It is worth reviewing first the factors which may have predisposed the French army to a collapse, and then to review the critical parts of the battle itself.

France as a nation, a very large group from the group process point of view, never really recovered from the trauma of WW I. Even though France was among the victors, that war had been largely fought on French territory and had left France in the paradoxical position of being economically and spiritually exhausted but believing that she possessed knowledge of the best ways to be successful in war. In the years following the war, France was subject to the economic upheaval that shook all the West. Throughout the existence of the Third Republic in France, internal politics were in turmoil. As Germany under Hitler after 1933 made a rapid recovery from depression, there were some among 
the French who were as sympathetic to the new style of government in Germany as they were to democracy. On the other side of the political spectrum, the Russian revolution after WW I produced ripples throughout Europe. There was a minority in France more attracted to the Russian form of government than to either traditional democracy or the new totalitarian style in Germany. The French were bitter when they did not receive the meaningful reparations from Germany after WW I that had been specified in the Versailles Treaty. In 1936 the first of many shocks hit France when Germany returned its army to the previously demilitarized Rhineland. At that time, France was stronger than Germany and probably could have invaded Germany successfully, causing Hitler's fall. France as was true of other countries (notably Russia) had no stomach to take on the containment of Hitler's Germany unilaterally.

In 1937 Hitler formally voided the Treaty of Versailles, and the period of real appeasement followed with the union of Germany and Austria in March 1938 and with the dismemberment of Czechoslovakia following the infamous meetings in Munich in September 1938. In March 1939 Germany gained control over all of Czechoslovakia and the myth of German invulnerability was well established. Germany had come from total collapse after WW I to economic recovery, and had conquered both Austria and Czechoslovakia without war. In individual psychology it is obvious that a life experience of repeated failure and humiliation severely decreases the ego's ability to react effectively to crisis. A similar process may be hypothesized as occurring in nations, that repeated appeasement and political failure decrease a nation's ability to respond to crisis.

Worse humiliation and stress were to follow for France in 1939. The SovietGerman non-aggression pact in August 1939 permitted Germany to dare to invade Poland in September 1939. Honouring prior agreements, France and Britain declared war on Germany, but the curious "phoney war" ("drole de guerre" or "Sitzkrieg") followed Poland's rapid defeat. Hitler felt safe during the invasion of Poland leaving his western flank entirely vulerable to the French (who could have mounted a devastating attack on the industrial heart of Germany) because he correctly judged that France had only a defensive posture and would not invade Germany. The "phoney war" was a particularly confusing period because of the invasion of Finland by Russia, which for a time led Britain and France to consider war on Russia as well as Germany. The German conquest of Denmark and Norway in early 1940 again stunned the west and reinforced the myth of German invulnerability. At that time the average French citizen must have had terrible, only partly conscious, conflicts about the nation as a whole. France, with her allies, had faced years of psychological defeat from Germany. If the French, however, saw German aggression elsewhere as invulnerable, they saw their own defence as impermeable. The Maginot line could protect against German invasion on the border with Germany between Switzerland and Luxembourg, and the best units of the French army were poised to protect against invasion through Holland and Belgium. The leaders of the French army were men who had experienced success in WW I, and who felt certain they could defend against the predicted pattern of any German invasion of France.

During the 1939-40 winter Hitler planned on many occasions to invade 
France, and many times postponed the invasion because of a variety of reasons, not the least of which was weather. Inadvertently, Germany created a "cry wolf" atmosphere in which the event of a genuine invasion might not be appreciated initially. When the actual invasion came in May 1940, it was a surprise, but the allies felt prepared. The strategy chosen by Germany was daring, and most German generals themselves were frightened by it. The successful strategy had been promoted by only a minority of German officers, primarily General Eric von Manstein, but strongly supported by Hitler. On May 10, 1940 Germany invaded Holland and Belgium on the obvious route, towards France. As planned, the strongest units of French army (with the British expeditionary force) rushed into Belgium to meet the Germans. In doing so they fell into a German trap because the Germans had reserved the strongest part of their army for the Blitzkrieg attack on France through Luxembourg and Belgium, just beyond the north end of the Maginot line and behind the allied forces in the north. On May 12, 1940, after crossing the presumedly impassible Ardennes region, the Germans attacked France and in the next two days consolidated important crossings over the Meuse River.

The weakest part of the French defences, the hinge between the Maginot line and the French-Belgian border was punctured by the German tank armies. In a matter of days, the Germans dashed across northern France, reached the sea, and cut the lines of communication to the allied armies in the north. Holland and Belgium had quickly fallen to the original German attack in the north, in part because Belgium's neutrality had delayed French and British movements into Belgium. The evacuation at Dunkirk took place. The collapse of the remaining French forces, armistice with Germany and the creation of the Vichy government of France followed in quick succession.

Quotes by participants and historians of that time are illustrative of the psychological collapse which was in many ways more important than the strategic and tactical defeats. General von Manstein, the architect of the invasion, alludes to psychological factors in the German victory. In the first quote, it should be noted that the "quality of the German armoured formation" was in their organization, not in the thickness of each tank's armour.

'The really decisive reason for the Allies' utter defeat in northern Belgium was still the surprise thrust through the Ardennes, across the Meuse to the Somme estuary and ultimately against the Channel harbours ${ }^{17}$, that the second phase of the German offensive so soon led to the total capitulation of the enemy is primarily due to his inability, after his losses in northern Belgium, to man adequately the whole of his front from the Swiss frontier to the sea. Another reason was that the morale of the French Army had already been badly dented-not to mention the fact that the enemy possessed nothing matching the quality of the German armoured formation ${ }^{18}$.'

In his Collapse of the Third Republic journalist and historian William Shirer fully explored France's weakness in 1940. Describing the crucial crossing into France at Sedan he wrote:

"From 11 a.m. on, the Germans softened up the French positions by incessant dive-bombing and gunfire .. The uninterrupted bombing, in effect, caused 
relatively little damage. But, besides pinning the artillerymen down so that they often gave up trying to fire, it was devastating to their morale ..." The gunners stopped firing (General Edmond Ruby reported) and took cover. The infantry, cowering and immobile in their trenches, dazed by the crash of bombs and the shriek of the dive bombers, were too stunned to use their anti-aircraft guns and fire. Their only concern was to keep their heads down and not move. Five hours of this punishment shattered their nerves. They became incapable of reacting to the approaching enemy infantry ${ }^{19}$, the 71 st Division still held, blocking the advance of the 10th Panzer. But now its left flank was threatened along the Ennemane river and it began to pull back, led by the divisional commander, who hastily moved his Command Post 7 miles to the rear. His troops quickly followed, though not pressed at all by the enemy, and soon there was another scene of wild disorder as foot soldiers and artillerymen abandoned their guns and, panicstricken, fled down the roads southward ${ }^{20}$."

The German army continued to plunge across northern France, always ahead of any efforts made by the French to organize an effective counter-attack. Perhaps the strongest suggestion that the fall of the French army during those days was more from psychological than from other causes is gained from a quote by General Beaufre who at that time was a junior officer serving in the French army headquarters.

"Attention was concentrated on the armoured spearhead of the German Army which was penetrating deeper and deeper towards the sea with the relentlessness of a train ... . Orders were given for various cutting-off operations, for stands 'to the death', nothing happened; nothing could slow up the advance. We knew exactly the strength of their advance guard; it consisted of a few dozen tanks with lorry-borne infantry and motor-cyclists; an officer had seen them and counted them. Warning had been given of their arrival but in spite of this all resistance evaporated. At Amiens the population and the local troops baled out at the simple news that the Germans were in the offing. Two guns and a hundred determined men could have held them up for half a day, but nowhere was there any real action. It was realized in all this that the problem was more than material. But how could people get a grip of themselves in the midst of this general chaos? ${ }^{21 "}$.

The history of France before and at the start of WW II is very painful for it is riddled with political battles, reluctance to give up WW I principles, economic turmoil, retreat from confrontation, and massive military defeat. Certainly, after the German invasion of the west in May 1940, the French soldiers and units fought bravely and effectively. For example, Charles DeGaulle (at that time a Colonel, whose ideas for use of armour had been adopted by the Germans but not the French) mounted an armoured counter-attack against the Germans as they crossed northern France. It had considerable local success, but was not followed up. Overall, the French had the material wherewithal to meet the German invasion, but they did not have the tactics or the political and military leadership. More important, they did not collectively have the fighting spirit, and when the battle hit, the French army was ineffective. Individual soldiers may have fought well, but the collectivity of the group process within the entire French nation too 
often rendered groups of soldiers ineffective. For practical purposes, the French army became a psychiatric casualty in May 1940.*

\section{The American Army: A Potential Psychiatric Casualty}

The American army of the $80 \mathrm{~s}$ particularly that third of it stationed in Europe, is a modern army appropriate to study from the point of view of armies being at risk of becoming psychiatric casualties. Is this powerful army at risk of collapsing in combat as a psychiatric casualty? In history, specifics of combat always produce surprises, and no accurate prediction may be made that in a major conflict any particular army will be precipitously defeated as was the French army in WW II. Nevertheless, the American Army is affected by a number of psychological risk factors which might influence its ability to cope with large scale combat, and it is imperative that these factors receive close attention from commanders.

Many examples of psychological risk factors in the American Army may be given. Army leadership suffered the trauma of not winning a major war in Viet $\mathrm{Nam}$, and controversies still rage over assignment of responsibility for that failure $^{22}$. Following the Viet Nam War, for several years a military career was questionable in many circles of the United States, and for a long period of time officers even at the Pentagon in Washington D.C. frequently did not wear their uniforms. The concept of the citizen soldier is not presently accepted in the United States, most clearly demonstrated by the inability of the army to recruit soldiers representing a cross section of American citizens and by the unwillingness of Americans in general to accept a draft at this time. Many senior military personnel consider aspects of the Modern Voluntary Army to be unsuccessful, but until recently political pressures made it almost impossible to examine weaknesses objectively. Recruiting for the military has emphasized the educational and travel benefits, and has not appealed to patriotism, defence of democracy or other ideals. There is sometimes a lack of meaningful military training in many sections of the army where peacetime work loads are far beyond what would be acceptable in the civilian community, and where meaningful military training would only mean increasing amounts of time at work. In Europe, there are over

* This paper has focused in detail on the French Army in WW II since it is a relatively recent example of a defeated army about which much is known. As time gives the perspective necessary for historical review, additional insights might be gained by studies of more recent examples of armies which have suffered major setbacks, such as the Egyptian Army in 1967 and the army of the Republic of Viet Nam in 1975. Furthermore, if one reflects on the United States in 1941 just after Pearl Harbour, what would have been American reaction had the attack been on San Francisco rather than Pearl Harbour, or if Japan had been contiguous to the United States rather than separated by thousands of miles of ocean? The American relocation of Japanese Americans on the West Coast of the United States refelected a near-panic reaction to Japanese military success. Would an actual attack on mainland America have been met by a united will to resist or by ineffectiveness in the face of early reversals? 
250,000 American dependants whom some cynics see as being like hostages, the assumption being that attack by potential enemies on "just soldiers" would not stir up the nation, but attack on civilians would. Many soldiers are sceptical of the effectiveness of plans to evacuate their dependants in time of crisis.

In Europe the American army has gradually shifted from the status of a conquering army after WW II to what might be seen as a mercenary army with a socio-economic status below that of host nations. In theory the American troops in Europe are closely allied with other NATO forces, but in fact most Americans in Europe do not speak a second language and in crisis might have difficulty communicating with allies. Many American soldiers lack sufficient knowledge of NATO equipment to enable them to take it up were their own equipment not available. For years it has been common knowledge that military material is often lacking or deficient in quality. The subject of army women in combat zones is difficult to study objectively because, like so many of the other factors that have an impact on the ability of soldiers to withstand the shock of combat, political considerations have often demanded that the presence of women in combat units be declared successful.

In psychiatric practice, fantasies are considered important because the psychic reality they represent often influences behaviour. Two common, potentially disastrous fantasies among some American troops in Germany are "why bother to prepare for combat, we'll all get wiped out anyway", and "if the balloon goes up (war starts), I'll grab my family and head for France or Switzerland". More risk factors could be added to the list, but the trend should be evident.

Positive signs exist, but need amplification. There are many examples of American leadership in Europe practising what amounts to preventive psychiatry in the form of good concerned leadership from the squad level to the highest command level. One also notes efforts to develop more credible non-combatant evacuation plans, with realistic discussion of risks involved. There have been significant efforts to address problems resulting from abuse by soldiers of alcohol and illicit drugs. Many units have good cohesiveness and regularly receive realistic training. Perhaps most significant, leaders have recently shown an increasing willingness to address publicly the risk factors which remain. Nevertheless, while the American Army in Europe may be combat ready in many areas, as a large group it must be considered to be at some risk of becoming a psychiatric casualty at a time of great crisis unless the most serious attention is given to the many risk factors which are easily identified but less easily addressed.

\section{Prevention of Group Psychiatric Casualties}

Combat psychiatric casualties in individual soldiers are effectively treated by principles alluded to earlier, and essentially consist of rest, with support of the soldier's sense of identification with his combat group. Appropriate treatment of psychiatric disability in groups is less clear. For armies disabled in combat effective treatment may be irrelevant because the battle may have already been lost. What treatment there is to be given probably is from good leadership, and the example of Petain reviving the failing French army late in WW I may be 
given ${ }^{23}$. With groups, however, failure is best avoided by good preventive treatment. Certainly good leadership is essential, but good fellowship (or in terms more relevant to an army, good citizenship) is equally important. It may safely be said that no army can be stronger than the citizens which form it and support it. A characteristic of any effective group is that every member feels a sense of responsibility for the performance of the entire group. Members of effective groups do not see their leaders as somehow beyond them, but as members who are given special roles based on their skills and experience. In effective groups members accept that group problems are problems for both leaders and followers, and they do not search for scapegoats.

\section{Conclusion}

An awareness that entire armies may in effect become psychiatric casualties may be useful for drawing attention to those psychological factors which weaken the potential of an army effectively to conclude its combat mission. Just as the psychological analysis of an individual person is always painful for that person, it may be assumed that for members of any group the psychological analysis of the group will be equally painful and perhaps even more difficult. One cannot put a large group like an army on a couch, but it is important nevertheless to analyze carefully those factors which predispose it to ineffectiveness in its combat task. For political or philosophical reasons some risk factors might have to be tolerated in an army, but if so the possibility that they are weakening the army's ability to address its primary task of combat should not be denied. Other risk factors, if clearly identified and studied, might be alleviated. At moments, though, when it is tempting to repress the possibility of armies becoming psychiatric casualties, one only has to remember the tragic example of France in 1940.

1 Richardson F M. Fighting Spirit. London. Leo Cooper: 1978.

2 Freud S. Totem and Taboo in Standard Edition of the Complete Works of Sigmund Freud. Vol. XIII. Hogarth Press. London: 1953.

3 Freud S. Group Psychology and the Analysis of the Ego in Standard Edition of the Complete Psychological Works of Sigmund Freud. Vol. XVIII. Hogarth Press. London: 1955 .

4 Colman A D and Bexton W H. Editors. Group Relations Reader. Grex., Sausilito. California: 1975.

5 Bron W R. Experiences in Groups. Tavistock Publications. London: 1959, also Basic Books. New York: 1961.

6 Rice A K. Learning for Leadership. Tavistock Publications. London: 1965.

7 Miller E J AND Rice A K. Systems of Organization. Tavistock Publication. London: 1967.

8 ReEs J R. The Shaping of Psychiatry by War. W W Norton. New York: 1945.

9 Glass A J. Ed of Neuropsychiatry. Medical Department, United States Army Neuropsychiatry in World War II, Vol II, Overseas Theaters. Office of the Surgeon General, Department of the Army, Washington, DC: 1973. 
10 Ingraham L H and Manning F J. Psychiatric Battle Casualties: The Missing Column in a War Without Replacements. Medical Bulletin of the US Army Europe. Vol 37 Dec 1980: 3-9.

11 Kaplan H I, Freedman A M and Sadock, B J Eds. Chapter 46. Military Psychiatry and Section 25.3 Traumatic War Disorders In Comprehensive Textbook of Psychiatry III. Williams \& Wilkins, Baltimore \& London: 1980.

12 ShIRER W L. The Collapse of the Third Republic. Simon \& Schuster. New York: 1969.

13 Guderian H. Panzer Leader. E P Dutton \& Co Inc. New York: 1952.

14 Von Manstein E. Lost Victories. Henry Regnery Co. Chicago: 1958.

15 Beaufre A. The Fall of France. Knopf. New York: 1968.

16 Deighton L. Blitzkreig. Jonathan Cape Ltd. Great Britain: 1979; also Knopf, New York: 1980.

17 Von Manstein. Op cit: Pg 24. 18. Von Manstein E. Op cit: Pg 646.

19 Shirer W L. Op cit: Pg 652.

21 Beaufre A. Op cit: Pg 188.

22 Gabriel R A and Savage P L. Crisis in Command. Hill \& Wang. New York: 1978.

23 Liddell Hart B H. History of the First World War. Pan Books. London: 1972: Pg 302; also by Cassell \& Co Ltd. Great Britain: 1970.

MRCGP

MRCPsych

DRCOG

\section{ACADEMIC ACHIEVEMENTS}

Capt S Boll, MB, BS. Capt K Hope, MB, BS, MRCS, LRCP. Capt M J O'B Minogue, MB, BChir. Maj D G Nevison-Andrews, MB, ChB.

Maj G Milligan, MB, ChB, BSc, MRCGP.

\section{Additional Qualifications}

Col A G Harwood, L/RAMC, has been appointed as a Member of the Faculty of Occupational Medicine.

Col T A Sanderson, L/RAMC, has been elected as an Associate of the Faculty of Occupational Medicine.

The undermentioned officers have been elected to the Fellowship of the Royal College of Obstetricians and Gynaecologists.

Col A M Michael, L/RAMC. Lt Col A M B Jackson, RAMC. Lt Col L A Lees, RAMC. 